\title{
Penyelenggaraan Pariwisata Olahraga: Perspektif Rekomendasi Pemerintah Daerah
}

\section{Aditya Putra Thama ${ }^{1}$, Ni Ketut Supasti Dharmawan ${ }^{2}$}

${ }^{1}$ Program Studi Magister Kenotariatan, Fakultas Hukum, Universitas Udayana, Bali-Indonesia, E-mail: adityaputrathama@yahoo.co.id

${ }^{2}$ Fakultas Hukum Universitas Udayana, Bali-Indonesia, E-mail: arasswk@yahoo.com

\begin{tabular}{l}
\hline Info Artikel \\
\hline Masuk: 11 Juni 2019 \\
Diterima: 15 Juli 2019 \\
Terbit: 21 Juli 2019 \\
\\
Keywords : \\
Sports Tourism; \\
Recommendations; Criminal \\
Sanction; Bali Provincial \\
Sports Regulations
\end{tabular}

Kata kunci:

Pariwisata Olahraga;

Rekomendasi; Sanksi Pidana; Perda Keolahragaan Provinsi Bali

\begin{abstract}
Current sports activities are quite closely related to tourism. Tourism is the main source of livelihood for the people of Bali. Along with the development of sports in Bali, the implementation of sports tourism was also developed as an option in the development of local tourism. Bali Provincial Sports Regulation regulates sports tourism in Bali. However, the provisions of Article 14 paragraph (2) of the regulation require regional government recommendations prior to the implementation of sports tourism, which if not fulfilled can be subject to criminal sanctions in contravention of the SKN Law and the implementing regulations give rise to norm conflicts. The purpose of this study is to study the implementation of sports tourism based on the Bali Province Sports Regulations and analyze criminal sanctions for not being given the recommendations of the regional government by the organizers. The method used in this study is a normative legal research method with a statutory approach. The results of the study show that based on the Bali Provincial Sports Regulations the implementation of sports tourism must obtain recommendations from the regional government as Article 14 paragraph (2) of the Provincial Regulation on Sport in Bali. However, higher legal provisions related to sports, namely the SKN Law does not regulate this. The SKN Law which is a reference for organizing sports only requires a recommendation from the relevant organization of sports branch as Article 51 paragraph (2). The criminal provisions as Article 65 paragraph (1) of the Bali Province Sports Regulations for organizers who do not have a recommendation from the regional government are irrelevant and seem excessive considering the recommendation is an administrative requirement for an activity, it will be more relevant if administrative sanctions are imposed rather than criminal sanctions. In the event that this occurs, it will refer to the provisions of the SKN Law as well as the implementation rules.
\end{abstract}

\footnotetext{
Abstrak

Kegiatan olahraga saat ini cukup erat kaitannya dengan pariwisata. Pariwisata merupakan sumber mata pencaharian utama bagi masyarakat Bali. Seiring dengan berkembangnya olahraga di Bali, penyelenggaraan pariwisata olahraga juga dikembangkan sebagai salah satu pilihan dalam pengembangan
} 


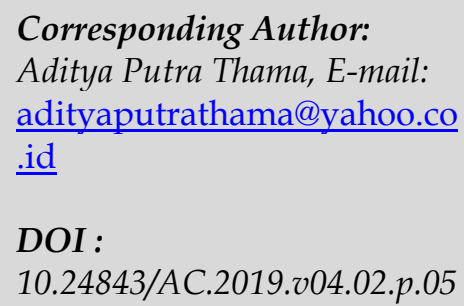

\section{Pendahuluan}

Dunia kepariwisataan setiap tahun memperlihatkan kemajuan-kemajuan yang lumayan pesat. Hal tersebut dikarenakan, antara lain oleh pergeseran struktur sosial ekonomi negara secara global dan semakin banyak orang yang mengantongi pundipundi penghasilan lebih yang semakin tinggi. Selain itu kepariwisataan juga bertransformasi menjadi sebuah fenomena global, menjadi kebutuhan hidup dan juga menjadi sarana untuk menunjang kinerja masyarakat. Bahkan berdasarkan kajian Supasti Dharmawan, kepariwisataan dalam hal ini berwisata, di mata dunia internasional telah menjadi bagian dari hak asasi manusia yang harus dihormati dan dilindungi keberadaannya. ${ }^{1}$ Dalam mengahadapi perubahan global dan penguatan hak pribadi masyarakat untuk menikmati waktu luang dengan berwisata, perlu dilakukan pembangunan kepariwisataan.

\footnotetext{
${ }^{1}$ Dharmawan, N. K. S., Nurmawati, N. M., \& Sarna, K. (2011). The Right to Tourism dalam Perspektif Hak Asasi Manusia di Indonesia. KERTHA PATRIKA, 36 (2), h.9-11.
} 
Di Indonesia, khususnya di Bali, pariwisata telah menjadi roda penggerak pembangunan ekonomi bagi masyarakat lokal. 2 Pembangunan kepariwisataan dibangun dan dikembangkan menggunakan pendekatan pertumbuhan dan pemerataan ekonomi untuk peningkatan taraf hidup masyarakat dan pembangunan yang berkiblat pada pengembangan daerah, bertumpu kepada masyarakat, dan bersifat mengedepankan pemberdayaan masyarakat yang mencakupi berbagai aspek, seperti sumber daya manusia, pemasaran, perjalanan, ilmu pengetahuan dan teknologi, keterkaitan lintas sektor, kerja sama antarnegara, pemberdayaan usaha kecil, serta tanggung jawab dalam pemanfaatan sumber kekayaan alam dan budaya. Berbicara mengenai kegiatan pariwisata, sesuatu yang umum terbayang adalah liburan, bepergian atau bersenang-senang di suatu lingkungan yang berbeda untuk menikmati hal baru. ${ }^{3}$

Definisi ini kemudian semakin berkembang dengan munculnya pariwisata sebagai industri sebagaimana yang terlihat dari pernyataan yang diberikan oleh United Nations World Tourism Organization (UNWTO) sebagai berikut:

"Tourism is a social, cultural, and economic phenomenon which entails the movement of people to countries or places outside their usual environment for personal or business/professional purposes."

"Tourism is a social, cultural, and economic phenomenon related to the movement of people to places outside their usual place of residence, pleasure being the usual motivation."

"A visitor is someone who is travelling under certain conditions, namely, for holiday, leisure and recreations, business, health, education or other purposes." 4

Jika diterjemahkan dalam bahasa Indonesia pariwisata merupakan fenomena sosial, budaya dan ekonomi yang membutuhkan perpindahan orang ke negara atau tempat selain lingkungan mereka yang biasa untuk tujuan perorangan atau bisnis/profesional. Dari definisi tersebut dapat dilihat bahwa motivasi wisatawan bukan lagi hanya sekedar menikmati hal baru atau menghabiskan liburan melainkan juga meluas kepada tujuan-tujuan pribadi, bisnis dan profesional. Pariwisata merupakan fenomena sosial, budaya, dan ekonomi yang terkait dengan perpindahan orang ke tempat-tempat selain tempat tinggal biasa mereka, dengan motivasi mendapatkan kesenangan. Wisatawan adalah seseorang yang bepergian dalam kondisi tertentu, yaitu, untuk liburan, rekreasi, bisnis, pendidikan, kesehatan, atau tujuantujuan lainnya.

Hal tersebut membuka peluang-peluang perluasan industri pariwisata. Berdasarkan ketentuan Pasal 1 angka 9 Undang-Undang Nomor 10 Tahun 2009 tentang Kepariwisataan (selanjutnya disebut UU Kepariwisataan) industri pariwisata adalah sekumpulan bisnis pariwisata yang saling berkaitan untuk memproduksi barang dan/atau jasa bagi pemuasan keperluan wisatawan dalam pelaksanaan pariwisata.

2 Widiatedja, I. G. N. P., Arsika, I. M. B., Satyawati, N. G. A. D., \& Landra, P. T. C. (2018). Retire in Paradise: Urgensi Pengaturan Pariwisata Pensiunan (Retirement Tourism) di Indonesia. ARENA HUKUM, 11 (1), h.2-4.

${ }^{3}$ Thama, A. P. (2019). The Settlement of Travel Bureau Role in The Development of Medical Tourism in Indonesia. Jurnal Hukum Prasada, 6(1), h.15-21.

${ }^{4}$ Nations, U. (2010). International Recommendations for Tourism Statistics. United Nations Publication Sales No. E.08.XVII.28, h.1. 
Salah satu peluang pengembangan industri pariwisata adalah dalam bidang pariwisata olahraga.

Saat ini kebutuhan akan olahraga bukan hanya dibutuhkan oleh kalangan olahragawan. Namun olahraga bisa dianggap sudah menjadi bagian dari pola hidup masyarakat di seluruh dunia. Berbagai jenis olahraga telah menjadi gaya hidup di kalangan masyarakat. Mulai dari olahraga ringan seperti jalan santai, jogging, atau senam. Olahraga permainan seperti bulutangkis, sepakbola atau basket sampai dengan olahraga ekstrem seperti surfing, skateboard, bahkan martial arts.

Di Bali, kegiatan keolahragaan juga mengalami perkembangan yang baik. Dari sisi kualitas prestasi, Bali mampu menduduki peringkat keenam saat perhelatan Pekan Olahraga Nasional (PON) Tahun 2016 di Jawa Barat. Bahkan Bali senantiasa melahirkan atlet-atlet yang menjadi andalan Indonesia untuk mendulang medali di event-event internasional seperti South-East Asia Games (SEA GAMES) 2017 di Malaysia maupun Asian Games 2018 saat Indonesia menjadi tuan rumah. ${ }^{5}$ Selain itu, kegiatankegiatan keolahragaan yang bersifat rekreasi di Bali juga mulai banyak diselenggarakan guna mendidik dan mengajak masyarakat menjaga pola hidup sehat dengan berolahraga, salah satunya fun run. ${ }^{6}$ Olahraga sebagai wahana rekreasi juga terdapat pada olahraga air. Berbagai jenis olahraga air dikembangkan untuk memberikan sensasi, tantangan, kepuasan kepada masyarakat seperti rafting, snorkeling, diving, parasailing, jet ski, dan lain sebagainya. ${ }^{7}$

Semakin diminatinya olahraga di Bali tentunya akan semakin memicu berkembangnya kegiatan-kegiatan keolahragaan. Hal ini juga menuntut para penyelenggara kegiatan olahraga agar senantiasa berinovasi dalam menyelenggarakan kegiatan olahraga sehingga minat masyarakat untuk terus berolahraga tetap terjaga. Salah satu cara untuk menjaga hal tersebut adalah dengan mengembangkan pariwisata olahraga.

Pengembangan di dunia keolahragaan, termasuk pariwisata olahraga, tidaklah dapat terlaksana dan bermanfaat dengan baik bila tanpa adanya aturan main yang jelas. Untuk itu Pemerintah Daerah Provinsi Bali menetapkan Peraturan Daerah Provinsi Bali Nomor 5 Tahun 2018 tentang Keolahragaan (selanjutnya disebut Perda Keolahragaan Provinsi Bali). Dengan ditetapkannya Perda Keolahragaan Provinsi Bali ini diharapkan mampu membawa kemajuan dalam keolahragaan khususnya di Bali.

Perda Keolahragaan Bali telah mengatur tentang pariwisata olahraga. Ketentuan Umum Perda Keolahragaan Bali Pasal 1 angka 30 menentukan bahwa pariwisata olahraga adalah suatu wujud perpaduan antara aktivitas olahraga dan destinasi dengan tujuan melakukan olahraga, serta menyelenggarakan pertunjukan-pertunjukan olahraga. Berdasarkan penjelasan ketentuan di atas dapat dikatakan bahwa pariwisata olahraga merupakan kombinasi antara kegiatan olahraga dan perjalanan wisata

\footnotetext{
${ }^{5}$ Nusa Bali. (2018). Hasil Asian Games, Momentum Anak Muda Bali. Available from https://www.nusabali.com/berita/37251/hasil-asian-games-momentum-anak-muda-bali. (Diakses tanggal 18 Maret 2019).

6 Bali Berkarya. (2019). Ajak Masyarakat Denpasar Hidup Sehat, Walikota Rai Mantra Buka Colour Fun Run IPC 2019. Retrieved from https://denpasarkota.go.id/bacaberita/14597/ Ajak-Masyarakat-Denpasar-Hidup-Sehatkoma-Walikota-Rai-Mantra-BukaColour-Fun-Run-IPC-Bali-2019-. (Diakses tanggal 18 Maret 2019).

7 Suparta, I. K., \& Triyuni, N. N. (2014). Tanggung Jawab Pengusaha Terhadap Wisatawan Pada Usaha Wisata Tirta di Bali. SOSHUM JURNAL SOSIAL DAN HUMANIORA, 4 (2), h.111.
} 
dengan tujuan untuk mendapatkan manfaat kesehatan sekaligus kesenangan. Secara singkat pariwiasata olahraga adalah kombinasi antara olahraga dengan pariwisata sebagaimana ditegaskan pada Pasal 13 ayat (1) Perda Keolahragaan Provinsi Bali. Lebih lanjut, melalui kegiatan pariwisata olahraga inilah kemudian dapat diarahkan kepada industri olahraga agar bisa menambah pundi-pundi penghasilan daerah dan pelaku olahraga menjadi lebih sejahtera serta dapat semakin memajukan dunia olahraga.

Industri olahraga merupakan suatu industri yang menghasilkan nilai lebih melalui produksi dan pengadaan olahraga terkait dengan peralatan dan servis (pelayanan) olahraga. ${ }^{8}$ Kemajuan industri olahraga cukup bernilai strategis karena sejatinya berkaitan dengan langkah-langkah dan strategi pemberdayaan ekonomi kerakyatan yang menyasar masyarakat menegah ke bawah dan diharap menjadi bagian dari strategi pengentasan dan mengurangi angka kemiskinan. Sektor olahraga yang identik dengan disiplin, kejujuran dan sportivitas dapat memberikan suasana yang kondusif bagi iklim usahanya sehingga dapat menjadi tolak ukur bahwa dengan membangun keolahragaan sebetulnya mempunyai manfaat yang sangat besar. Bukan sekedar terbatas pada kelompok-kelompok olahraga, namun juga masyarakat luas, sehubungan dengan kesejahteraan sosial, termasuk juga para pelaku pariwisata dalam kaitannya dengan pariwisata olahraga. ${ }^{9}$

Berkenaan dengan penyelenggaraan pariwisata olahraga, Perda Keolahrgaaan Provinsi Bali Pasal 14 ayat (2) menentukan bahwa penyelenggara kegiatan wajib untuk mengantongi rekomendasi dari Pemerintah Daerah sebelum melaksanakan kegiatannya. Sementara itu, berkaitan dengan rekomendasi dalam penyelenggaraan kegiatan olahraga, berdasarkan Pasal 51 ayat (2) UU SKN, hanya penyelenggara kegiatan olahraga yang mendatangkan langsung massa penonton yang wajib mendapatkan rekomendasi dan itupun rekomendasi dari induk cabang olahraga yang bersangkutan.

Adanya kewajiban untuk mendapatkan rekomendasi-rekomendasi ini dapat menjadi faktor penghambat pengembangan keolahrgaan secara umum maupun pariwisata olahraga khususnya. Selain itu, adanya 2 ketentuan wajib rekomendasi yang berbeda ini justru dapat menimbulkan konflik norma. Untuk itu pemahaman mengenai pengaturan pariwisata olahraga di Bali dan urgensi kewajiban memperoleh rekomendasi Pemerintah Daerah dalam penyelenggaraan periwisata olahraga menjadi penting untuk perkembangan di sektor olahraga di Bali.

\section{Metode Penelitian}

Jenis penelitian yang digunakan dalam penulisan ini adalah jenis penelitian hukum normatif karena berangkat dari adanya konflik norma antara UU SKN dan Perda Keolahragaan Provinsi Bali. ${ }^{10}$ Jenis penelitian hukum normatif dilakukan dengan cara

${ }^{8}$ Utomo, A. W. (2018). Perkembangan Industri Olahraga Obyek Wisata dan Rekreasi di Kabupaten Magetan. In Prosiding Seminar Nasional Ilmu Keolahragaan UNIPMA, 1 (1), h.116-126.

${ }^{9}$ Kristiyanto, A. (2011). Penguatan Kebijakan Publik Usaha Pengentasan Kemiskinan Melalui Pengembangan Industri Mikro Olahraga. JURNAL EKONOMI PEMBANGUNAN, 12 (2), h.200-211.

${ }^{10}$ Soekanto, S., \& Mamudji, S. (2001). Penelitian Hukum Normatif (Suatu Tinjauan Singkat). Jakarta: Rajawali Press, h.15. 
melakukan penelitian terhadap bahan-bahan kepustakaan dengan melangsungkan riset terhadap persoalan-persoalan hukum kemudian dilakukan pengkajian menggunakan pendekatan perundang-undangan. ${ }^{11}$ Adapun peraturan perundang-undangan yang dikaji adalah UU Kepariwisataan, UU SKN, PP Nomor 16 Tahun 2007 tentang Penyelenggaraan Keolahragaan, PP Nomor 50 Tahun 2011 tentang RIPPARNAS, Permenpar Nomor 18 Tahun 2016, dan Perda Keolahragaan Provinsi Bali.

\section{Hasil Dan Pembahasan}

\subsection{Pengaturan Pariwisata Olahraga di Bali}

Pengembangan pariwisata olahraga yang diarahkan kepada percepatan pembangunan industri olahraga (sport industry) butuh benar-benar diberikan perhatian agar dapat menghasilkan sumber daya manusia yang maju dan lebih transformatif yakni masyarakat maju baik secara struktural maupun kultural. Aspek struktural terlihat pada langkah-langkah mengubah masyarakat yang sebelumnya hanya bersifat agraris bertransformasi menuju masyarakat industri yang disokong oleh dua pokok kekuatan yakni industri yang kokoh ditopang dengan kemampuan di sektor pertanian yang mumpuni mencakup keahlian teknologi yang mutakhir dan berkarakter lebih kompetitif. Sedangkan pada aspek kultural direfleksikan pada tradisi-tradisi positif baru yang bertumbuh kembang dan sangat berguna untuk mendongkrak pembentukan masyarakat industri olahraga yakni terkait dengan polatingkah laku, attitude rasional manusia, sadar terhadap gaya hidup sehat, dan memiliki jiwa berdaya saing. ${ }^{12}$

Pemerintah, dalam hal ini Kementerian Pariwisata, telah melakukan upaya untuk mendukung berkembangnya industri olahraga, khususnya pariwisata olahraga. Dukungan itu dilakukan dengan mengakomodir beberapa olahraga masuk ke dalam bidang-bidang usaha pariwisata yakni bidang usaha penyelenggaraan kegiatan hiburan dan rekreasi serta bidang usaha wisata tirta. Hal tersebut diatur pada Peraturan Menteri Pariwisata Nomor 18 Tahun 2016 tentang Pendaftaran Usaha Pariwisata (selanjutnya disebut Permenpar Nomor 18 Tahun 2016).

Pasal 12 ayat (1) huruf a Permenpar Nomor 18 Tahun 2016 menentukan sektor bisnis pelaksanaan aktivitas hiburan dan rekreasi meliputi jenis usaha gelanggang rekreasi olahraga. Selanjutnya Pasal 12 ayat (2) Permenpar Nomor 18 Tahun 2016 menentukan bahwa gelanggang rekreasi olahraga sebagaimana dimaksud pada ayat (1) huruf a meliputi subjenis: lapangan golf; rumah bilyar; gelanggang renang; lapangan tenis; gelanggang bowling. Selanjutnya Pasal 13 Permenpar Nomor 18 Tahun 2016 menentukan bahwa bidang bisnis wisata tirta meliputi jenis usaha: wisata arung jeram; wisata dayung; wisata selam; wisata memancing; wisata selancar; wisata olahraga tirta; dan dermaga wisata.

Berdasarkan ketentuan-ketentuan pasal tersebut dapat dilihat bahwa Pemerintah senantiasa berupaya mendukung berkembangnya industri olahraga yang berkaitan dengan jasa pariwisata olahraga. Sementara itu dalam rangka melakukan pengembangan pariwisata olahraga di Bali tentunya dibutuhkan juga

11Ibrahim, J. (2007). Teori, Metode dan Penelitian Hukum Normatif. Malang: Bayumedia, h.300.

12 Farida, M. (2012). Pemberdayaan Industri Olahraga dalam Menghadapi Pasar Bebas Proceeding Seminar Nasional UNY, h.2 
payung hukum yang menjadi landasan bagi para pelaku pariwisata olahraga di Bali. Untuk itu Pemerintah Provinsi hendaknya dapat mengahadirkan payung hukum tersebut. Pengaturan pariwisata olahraga di Bali dari sisi keolahragaan saat ini selangkah lebih maju daripada sebelumnya. Jika sebelumnya pariwisata olahraga belum diatur, saat ini pariwisata olahraga sudah diatur melalui Perda Keolahragaan Provinsi Bali. Dalam Perda Keolahragaan Provinsi Bali tersebut, pariwisata olahraga diatur pada Bagian Keempat Pasal 13 dan Pasal 14.

Perda Keolahragaan Provinsi Bali Pasal 13 menentukan bahwa pariwisata olahraga merupakan kombinasi aktivitas olahraga dengan perjalanan wisata. Kombinasi tersebut dilakukan guna mendapatkan manfaat kesehatan, kebugaran, kenyamanan dan kesenangan; mengangkat potensi dan keterampilan keolahragwan baik olahragawan amatir maupun professional; serta membuka kesempatan terhadap sumber pemasukan keolahragaan.

Jika dilihat lebih dalam terkait dengan ketentuan Pasal 13 Perda Keolahragaan Provinsi Bali di atas, kegiatan olahraga diharapkan tidak semata bertujuan untuk memperoleh kesehatan ataupun kebugaran, tetapi juga dapat menghadirkan kenyamanan dan kesenangan bagi para pelakunya. Untuk itu aspek pariwisata disisipkan dalam kegiatan olahraga sehingga dapat menghadirkan kesehatan, kebugaran, kenyamanan dan kesenangan dalam satu kegiatan pariwisata olahraga bagi para pelaku olahraga. Pengaturan kegiatan pariwisata olahraga juga dimaksudkan agar dapat memberikan peluang atas sumber dana keolahragaan di Bali. Dengan terbukanya peluang atas sumber dana keolahragaan, maka semakin terbuka juga peluang atas kemajuan keolahragaan di Bali, baik dari sisi prestasi maupun industri.

Perda Keolahragaan Provinsi Bali Pasal 14 ayat (1) menentukan bahwa aktivitas pariwisata olahraga dilakukan dan ditujukan untuk terciptanya industri olahraga yang bisa menambah penghasilan daerah, dan meningkatkan taraf hidup pelaku olahraga menjadi lebih sejahtera serta memajukan dunia olahraga. Berdasarkan ketentuan Pasal 14 ayat (1) tersebut dapat dikatakan bahwa pariwisata olahraga ini merupakan embrio dari industri olahraga. Lebih lanjut, industri olahraga diharapkan mampu mendongkrak pendapatan daerah, meningkatkan kesejahteraan pelaku olahraga termasuk penyelenggara pariwisata olahraga. Dari uraian tersebut dapat dilihat adanya cita-cita mulia yang menjadi tujuan daripada negara Indonesia yakni memajukan kesejahteraan umum yang dituangkan ke dalam sebuah bentuk peraturan perundang-undangan dengan harapan mampu memberikan kepastian hukum. Sedangkan Pasal 14 ayat (2) Perda Keolahragaan Provinsi Bali mengatur tentang adanya kewajiban setiap penyelenggara pariwisata olahraga untuk memperoleh rekomendasi dari Pemerintah Provinsi sebelum melaksanakan kegiatannya.

Lebih lanjut, Perda Keolahragaan Provinsi Bali ini mengamanatkan terbentuknya Peraturan Gubernur Provinsi Bali (selanjutnya disebut Pergub Provinsi Bali) mengenai pelaksanaan pengembangan pariwisata olahraga di Bali sebagaimana diatur dalam Pasal 14 ayat (3). Hal inilah yang perlu didorong agar segera diselesaikan sehingga dapat memberikan aturan main yang lebih jelas dan menjamin kepastian hukum bagi para penggiat pariwisata olahraga di Bali. Dengan dibentuknya Pergub Provinsi Bali tentang pelaksanaan pengembangan pariwisata olahraga sebagai aturan pelaksana akan dapat mempercepat 
industrialisasi olahraga di Bali yang akan bermuara pada kemajuan masyarakat, baik transformasi gaya hidup masyarakat maupun tingkat kesejahteraan masyarakat, khususnya masyarakat Bali.

\subsection{Urgensi Rekomendasi Pemerintah Daerah dalam Penyelenggaraan Pariwisata Olahraga}

\subsubsection{Penyelenggaraan Pariwisata Olahraga sebagai Bagian dari Penyelenggaraan Keolahragaan}

Pariwisata olahraga merupakan kombinasi antara kegiatan olahraga dengan kegiatan perjalanan wisata. Perjalanan wisata yang dimaksud yakni perjalanan yang bertujuan untuk berolahraga, menyaksikan olahraga, dan melakukan pertunjukan-pertunjukan olahraga. Hal tersebut sebagaimana ketentuan umum Pasal 1 angka 30 Perda Keolahrgaan Provinsi Bali.

Penyelenggaran keolahragaan di Indonesia secara umum diatur dalam UndangUndang Nomor 3 Tahun 2005 tentang Sistem Keolahragaan Nasional (selanjutnya disebut UU SKN). UU SKN Pasal 5 menentukan bahwa keolahragaan dilangsungkan berdasarkan prinsip-prinsip antara lain demokratis, tidak diskriminatif dan menjunjung tinggi nilai keagamaan, nilai budaya, dan keberagaman bangsa; keadilan sosial dan nilai kemanusiaan yang beradab; sportivitas dan menjunjung tinggi nilai etika dan estetika; pembudayaan dan transparansi; pengembangan kebiasaan hidup sehat dan aktif bagi masyarakat; pemberdayaan peran serta masyarakat; keselamatan dan keamanan; dan keutuhan jasmani dan rohani.

Adapun Peraturan Pemerintah Republik Indonesia Nomor 16 Tahun 2007 tentang Penyelenggaraan Keolahragaan (selanjutnya disebut PP Nomor 16 Tahun 2007) merupakan peraturan pelaksanaan dari UU SKN. Maka penyelenggaraan pariwisata olahraga sebagai bagian dari penyelenggaraan keolahragaan sebaiknya tetap menerapkan prinsip-prinsip sebagaimana Pasal 5 UU SKN dan berdasarkan pada PP Nomor 16 Tahun 2007. Jika dicermati lebih dalam tujuan pariwisata olahraga sebagaimana ditentukan pada Pasal 13 ayat (2) huruf a Perda Keolahragaan Provinsi Bali yakni untuk memperoleh kesehatan, kebugaran, kenyamanan, dan kesenangan ini memiliki kesamaan dengan tujuan dari pembinaan dan pengembangan olahraga rekreasi. Berdasarkan Peraturan Pemerintah Republik Indonesia Nomor 16 Tahun 2007 tentang Penyelenggaraan Keolahragaan (selanjutnya disebut PP Nomor 16 Tahun 2007) Pasal 30 ayat (1) menentukan bahwa:

"Pengembangan dan pembinaan olahraga rekreasi memiliki tujuan untuk meningkatkan kesadaran masyarakat dalam rangka memelihara dan menjaga kesehatan, kebugaran, kesenangan, dan hubungan sosial."

Berdasarkan ketentuan tersebut terdapat kesamaan antara pariwisata olahraga dengan olahraga rekreasi adalah pada tiga aspek tujuan yakni kesehatan, kebugaran, dan kesenangan.

Selanjutnya Pasal 31 ayat (1) PP Nomor 16 Tahun 2007 menentukan bahwa pengembangan dan pembinaan olahraga rekreasi menjadi tanggung jawab dan wewenang Menteri Pemuda dan Olahraga (selanjutnya disebut Menpora) dan 
menteri yang melaksanakan ihwal pemerintahan di sektor pariwisata (selanjutnya disebut Menpar). Artinya bahwa Menpora dan Menpar bertanggung jawab atas penyelenggaraan olahraga rekreasi, dan dalam melaksanakan tanggung jawab tersebut Menpora dan Menpar harus menjalin kemitraan dan bersinergi satu sama lain dalam rangka mencapai tujuan keberlangsungan olahraga rekreasi. Hal ini lagi-lagi menunjukkan kesamaan antara pariwisata olahraga dengan olahraga rekreasi.

Dalam pengembangan dan pembinaan olahraga rekreasi juga melibatkan peran masyarakat dan pemerintah daerah (selanjutnya disebut Pemda), dalam hal ini Pemerintah Provinsi. Hal tersebut sesuai dengan ketentuan Pasal 32 PP Nomor 16 Tahun 2007 yang menentukan bahwa Pemda dan masyarakat memiliki kewajiban menghadirkan sarana dan prasarana olahraga rekreasi sesuai kemampuan sumber daya wilayah/daerah masing-masing; Pemda bersama masyarakat menyiapkan fasilitas pembentukan sanggar olahraga dan perkumpulan/klub olahraga dalam lingkungan masyarakat; Pemda memberikan fasilitas festival dan kejuaraan olahraga rekreasi tingkat daerah yang dilaksanakan oleh masyarakat setempat; Pemda dapat memberikan fasilitas pelaksanaan kegiatan festival dan kejuaraan olahraga rekreasi baik nasional maupun internasional.

Berdasarkan kesamaan-kesamaan antara pariwisata olahraga dengan olahraga rekreasi yang diuraikan tersebut di atas maka penyelenggaraan pariwisata olahraga sebagai bagian dari penyelenggaran keolahrgaan hendaknya mengacu pada Pasal 30, Pasal 31, dan Pasal 32 PP Nomor 16 Tahun 2007 dengan tetap menjunjung tinggi prinsip-prinsip penyelenggaraan keolahragaan sebagaimana ketentuan Pasal 5 UU SKN.

\subsubsection{Peran Pemerintah Daerah dalam Penyelenggaraan Pariwisata Olahraga}

Penyelenggaraaan pariwisata olahraga sebagai bagian dari penyelenggaraan keolahragaan mengacu kepada UU SKN dan PP Nomor 16 Tahun 2007 sebagai peraturan pelaksanaannya. Dalam penyelenggaraan keolahragaan, Pemda dalam hal ini Pemerintah Provinsi sangat berperan. Pada Pasal 6 ayat (1) PP Nomor 16 Tahun 2007 menentukan bahwa Pemda berperan dalam melaksanakan tugas kebijakan keolahragaan nasional di daerah dan melaksanakan standardisasi keolahragaan nasional di daerah.

Kebijakan nasional keolahragaan tersebut meliputi penyelenggaraan olahraga pendidikan, olahraga rekreasi, dan olahraga prestasi; pembinaan dan pengembangan olahraga; penyelenggaraan kejuaraan olahraga; pembinaan dan pengembangan pelaku olahraga; pembinaan, pengembangan, dan pengawasan olahraga profesional; peningkatan kualiatas dan kuantitas prasarana dan sarana olahraga; pendanaan keolahragaan; pengembangan ilmu pengetahuan dan teknologi keolahragaan; peran serta masyarakat dalam kegiatan keolahragaan; pengembangan kerja sama dan informasi keolahragaan; pembinaan dan pengembangan industri olahraga; penyelenggaraan akreditasi dan sertifikasi; pencegahan dan pengawasan terhadap doping; pemberian penghargaan. Hal tersebut sebagaimana ketentuan Pasal 3 PP Nomor 16 Tahun 2007.

Berdasarkan ketentuan Pasal 8 PP Nomor 16 Tahun 2007 gubernur selaku kepala pemerintahan tingkat provinsi berperan dalam mengoordinasikan pelaksanaan tugas penyelenggaraan keolahragaan di provinsi secara terpadu dan 
berkesinambungan. Koordinasi pelaksanaan tugas penyelenggaraan keolahragaan tersebut mencakup semua aspek kebijakan nasional keolahragaan. Koordinasi tersebut dilaksanakan melalui rapat koordinasi provinsi, rapat kerja provinsi, dan/atau rapat konsultasi provinsi yang diselenggarakan secara hierarki intra sectoral, fungsional lintas sektoral, dan instansional multi sektoral, baik secara vertikal maupun horisontal.

Selain itu, sebagaimana ketentuan Pasal 13 ayat (2) UU SKN menentukan bahwa Pemda mempunyai kewenangan untuk mengatur, membina, mengembangkan, melaksanakan, dan mengawasi penyelenggaraan keolahragaan di daerah. Dalam melaksanakan kewenangan tersebut Pemda dapat mengikutsertakan komite olahraga provinsi, organisasi cabang olahraga tingkat provinsi, organisasi cabang olahraga fungsional tingkat provinsi, masyarakat, dan/atau pelaku usaha sesuai dengan ketentuan Pasal 11 ayat (3) PP Nomor 16 Tahun 2007.

Berdasarkan kewenangan sebagaimana dimaksud Pasal 13 ayat (2) UU SKN tersebut Pemda Provinsi Bali mengundangkan Perda Keolahragaan Provinsi Bali yang juga telah mengatur Pariwisata Olahraga. Pariwisata olahraga diatur pada Pasal 1 angka 30, Pasal 13 ayat (1), Pasal 13 ayat (2), Pasal 14 ayat (1), Pasal 14 ayat (2), Pasal 14 ayat (3), Pasal 65 ayat (1), dan Pasal 65 ayat (2). Dalam Perda Keolahragaan Provinsi Bali ini peran Pemda terhadap penyelenggaraan pariwisata olahraga terlihat pada Pasal 14 ayat (2) dan Pasal 14 ayat (3).

Pada Pasal 14 ayat (2) terlihat peran pemda dalam memberikan rekomendasi kepada penyelenggara kegiatan sebelum menyelenggarakan kegiatannya. Dalam pasal tersebut ditentukan bahwa rekomendasi pemda merupakan hal yang wajib didapatkan oleh penyelenggara. Sedangkan Pasal 14 ayat (3) menentukan bahwa ketentuan lebih lanjut mengenai pelaksanaan pengembangan pariwisata olahraga diatur dalam Pergub. Dalam pasal tersebut terlihat peran Pemda dalam membentuk Pergub mengenai pengembangan pariwisata olahraga.

\subsubsection{Rekomendasi dalam Penyelenggaraan Keolahragaan}

UU SKN maupun PP Nomor 16 Tahun 2007 mengatur terkait adanya rekomendasi dalam penyelenggaraan keolahragaan nasional. Dalam UU SKN ketentuan yang terkait rekomendasi diatur pada Pasal 51 ayat (2), Pasal 62 huruf b, Pasal 65 huruf b, dan Pasal 67 ayat (7). Sedangkan dalam PP Nomor 16 Tahun 2007 ketentuan yang terkait rekomendasi diatur pada Pasal 57 ayat (2) huruf e, Pasal 64 huruf f, Pasal 65 huruf e, Pasal 67 ayat (1) huruf f, Pasal 123 ayat (4), Pasal 123 ayat (5) dan Pasal 123 ayat (7). Di antara pasal-pasal tersebut, kewajiban penyelenggara kegiatan olahraga untuk mendapatkan rekomendasi diatur pada Pasal 51 ayat (2) UU SKN.

Pasal 51 ayat (2) UU SKN menentukan bahwa penyelenggara kejuaraan olahraga yang mendatangkan langsung massa penonton wajib mendapatkan rekomendasi dari induk organisasi cabang olahraga yang bersangkutan dan memenuhi peraturan perundang-undangan. Lebih lanjut, setiap penyelenggara kejuaraan olahraga yang tidak memenuhi kewajiban tersebut dikenakan ketentuan pidana dengan pidana penjara paling lama 2 (dua) tahun dan/atau denda paling banyak Rp 1.000.000.000,- (satu miliar rupiah) sebagaimana Pasal 89 ayat (1) UU SKN. Dari ketentuan tersebut dapat dilihat bahwa yang wajib mendapatkan rekomendasi hanyalah penyelenggara yang mendatangkan massa penonton secara 
langsung. Dan rekomendasi tersebut adalah rekomendasi yang dikeluarkan oleh induk cabang olahraga yang bersangkutan. Adapun pelanggaran terhadap kewajiban ini diancam dengan ketentuan pidana sebagai upaya mencegah gangguan terhadap keamanan maupun ketertiban umum yang disebabkan oleh datangnya massa penonton secara langsung.

Perbedaan yang mendasar terlihat antara ketentuan Pasal 51 ayat (2) UU SKN tersebut dengan ketentuan Pasal 14 ayat (2) Perda Keolahragaan Provinsi Bali. Pasal 14 ayat (2) tersebut menentukan bahwa setiap penyelenggara pariwisata olahraga wajib mendapatkan rekomendasi dari Pemda. Pelanggaran terhadap ketentuan ini pun diancam dengan ancaman pidana kurungan paling lama 3 (tiga) bulan atau pidana denda paling banyak Rp 50.000.000,- (lima puluh juta rupiah) sebagaimana Pasal 65 ayat (1) Perda Keolahragaan Provinsi Bali. Artinya setiap penyelenggara, tanpa terkecuali, wajib mendapatkan rekomendasi dan rekomendasi tersebut dikeluarkan oleh Pemda.

\subsubsection{Urgensi Rekomendasi Pemerintah Daerah terhadap Penyelenggaraan Pariwisata Olahraga}

Pasal 14 ayat (2) Perda Keolahragaan Provinsi Bali menentukan kewajiban penyelenggara pariwisata olahraga untuk mengantongi rekomendasi Pemda sebelum menyelenggarakan kegiatannya. Lebih lanjut pelanggaran terhadap ketentuan tersebut dapat dikenakan ketentuan pidana yakni pidana kurungan paling lama 3 (tiga) bulan atau pidana denda paling banyak Rp 50.000.000,- (lima puluh juta rupiah) sebagaimana Pasal 65 ayat (1) Perda Keolahragaan Provinsi Bali.

Jika demikian, maka rekomendasi Pemda dalam hal ini Pemerintah Provinsi Bali menjadi krusial karena jika pihak penyelenggara kegiatan pariwisata olahraga tidak mengantongi rekomendasi tersebut dapat dikategorikan sebagai tindak pidana. ${ }^{13}$ Adapun tindak pidana dimaksud merupakan pelanggaran sebagaimana ketentuan Pasal 65 ayat (2) Perda Keolahragaan Provinsi Bali. Dalam Perda Keolahragaan Provinsi Bali, yang dimaksud dengan rekomendasi tersebut tidaklah dijelasakan dalam penjelasan pasal 14 ayat (2).

Rekomendasi dapat berarti saran yang menganjurkan, membenarkan, menguatkan secara lisan. Dapat juga berarti meminta perhatian bahwa orang yang disebut dapat dipercaya, biasanya dinyatakan dalam bentuk surat. ${ }^{14}$ Dari pengertian-pengertian tersebut dapat ditafsirkan bahwa rekomendasi yang dimaksud dalam Perda Keolahragaan Provinsi Bali merupakan sebuah surat yang dikeluarkan oleh Pemda yang wajib diperoleh oleh setiap penyelenggara kegiatan pariwisata olahraga. Surat tersebut diperoleh dengan cara mengajukan permohonan kepada Pemda.

Pengaturan penyelenggaraan pariwisata olahraga sebagai bagian dari penyelenggaraan keolahragaan idealnya haruslah mengacu pada UU SKN yang dalam hal ini merupakan lex superior dari peraturan keolahragaan. Bahwa UU

${ }^{13 R a d i o ~ R e p u b l i k ~ I n d o n e s i a . ~(2018) . ~ P e r d a ~ K e o l a h r a g a a n: ~ B a b a k ~ B a r u ~ S p o r t ~ T o u r i s m ~ d i ~ B a l i . ~}$ Retrieved from http://rri.co.id/post/berita/605424/berita_olahraga/perda_keolahragaan_babak_baru_spor t_tourism_di_bali.html. (Diakses tanggal 18 Maret 2019).

${ }^{14}$ KBBI. (2019). Retrieved from https:// kbbi.web.id/rekomendasi (diakses tanggal 18 Juli 2019). 
SKN hanya mewajibkan penyelenggara kegiatan olahraga yang mendatangkan langsung massa penonton untuk mendapatkan rekomendasi dan rekomendasi tersebut berasal dari induk cabang olahraga yang bersangkutan bukanlah Pemda, maka dengan menggunakan asas hierarki (lex superior derogat legi inferiori) ketentuan Pasal 14 ayat (2) Perda dapat dikesampingkan.

Jika dilihat lebih dalam, urgensi Pemda untuk mewajibkan setiap penyelenggara pariwisata olahraga mendapatkan rekomendasinya sejatinya tidak ada. Apalagi pelanggaran terhadap ketentuan tersebut diancam dengan pidana. Hal tersebut sangatlah tidak relevan mengingat rekomendasi tersebut sifatnya adalah administratif. Dan juga kegiatan pariwisata olahraga bukanlah hal yang dapat mengangggu keamanan maupun ketertiban umum seperti kejuaraan olahraga yang mendatangkan langsung massa penonton. Maka akan lebih tepat bila pelanggaran terhadap ketentuan tersebut dikenakan sanksi administratif sebagaimana Pasal 64 Perda Keolahragaan Provinsi Bali.

Jika ingin diselaraskan dengan UU SKN khususnya ketentuan Pasal 51 ayat (2) maka semestinya penyelenggara pariwisata olahraga wajib mendapatkan rekomendasi dari induk organisasi cabang olahraga bersangkutan. Manakala Pemda melaksanakan pengawasan terhadap penyelenggaraan pariwisata olahraga, Pemda berwenang untuk meminta laporan dari induk cabang olahraga yang bersangkutan melalui pengurus induk cabang olahraga yang bersangkutan. Dengan demikian, tidak hanya meringankan beban penyelenggara pariwisata olahraga tapi juga terjadi sinergitas antara penyelenggara, induk cabang olahraga, dan Pemda.

\section{Kesimpulan}

Pariwisata olahraga di Bali diatur pada Perda Keolahragaan Provinsi Bali Pasal 13 dan Pasal 14. Pariwisata olahraga merupakan embrio dari industri olahraga. Lebih lanjut, industri olahraga diharapkan bisa mendongkrak pemasukan daerah, meningkatkan taraf hidup para penggiat olahraga termasuk penyelenggara pariwisata olahraga. Melalui Perda Keolahragaan Provinsi Bali, dapat dilihat adanya cita-cita mulia yang menjadi tujuan daripada negara Indonesia yakni memajukan kesejahteraan umum, dalam hal ini melalui pariwisata olahraga yang dituangkan ke dalam sebuah bentuk peraturan perundang-undangan dengan harapan mampu memberikan kepastian hukum. Pengaturan penyelenggaraan pariwisata olahraga sebagai bagian dari penyelenggaraan keolahragaan idealnya haruslah mengacu pada UU SKN maupun peraturan pelaksanaannya. Bahwa UU SKN hanya mewajibkan penyelenggara kegiatan olahraga yang mendatangkan langsung massa penonton untuk mendapatkan rekomendasi dan rekomendasi tersebut berasal dari induk cabang olahraga yang bersangkutan bukanlah Pemda, maka pengaturan penyelenggaraan pariwisata olahraga dalam Perda Keolahragaan Provinsi Bali semestinya tidak mengatur rekomendasi Pemda tersebut sehingga tidak terjadi pertentangan norma.

Jika ingin diselaraskan dengan UU SKN khususnya ketentuan Pasal 51 ayat (2) maka semestinya penyelenggara pariwisata olahraga wajib mendapatkan rekomendasi dari induk organisasi cabang olahraga bersangkutan. Mengingat rekomendasi sifatnya adalah administratif, maka akan lebih tepat bila pelanggaran terhadap ketentuan tersebut dikenakan sanksi administratif sebagaimana Pasal 64 Perda Keolahragaan 
Provinsi Bali. Manakala Pemda melakukan pengawasan terhadap penyelenggaraan pariwisata olahraga, Pemda dapat mewajibkan induk cabang olahraga yang bersangkutan melalui pengurus untuk memberikan laporan terkait penyelenggaraan pariwisata olahraga.

\section{Daftar Pustaka}

\section{Buku}

Ibrahim, J. (2007). Teori, Metode dan Penelitian Hukum Normatif. Malang: Bayumedia.

Soekanto, S., \& Mamudji, S. (2001). Penelitian Hukum Normatif (Suatu Tinjauan Singkat). Jakarta: Rajawali Press.

\section{Jurnal}

Dharmawan, N. K. S., Nurmawati, N. M., \& Sarna, K. (2011). The Right to Tourism dalam Perspektif Hak Asasi Manusia di Indonesia. KERTHA PATRIKA, 36 (2), h.9-11.

Farida, M. (2012). Pemberdayaan Industri Olahraga dalam Menghadapi Pasar Bebas. Proceeding Seminar Nasional UNY, h.2

Kristiyanto, A. (2011). Penguatan Kebijakan Publik Usaha Pengentasan Kemiskinan Melalui Pengembangan Industri Mikro Olahraga. JURNAL EKONOMI PEMBANGUNAN, 12 (2), h.200-211.

Nations, U. (2010). International Recommendations for Tourism Statistics. United Nations Publication Sales No. E.08.XVII.28, h.1.

Suparta, I. K., \& Triyuni, N. N. (2014). Tanggung Jawab Pengusaha Terhadap Wisatawan Pada Usaha Wisata Tirta di Bali. SOSHUM JURNAL SOSIAL DAN HUMANIORA, 4 (2), h.111.

Thama, A. P. (2019). The Settlement of Travel Bureau Role in The Development of Medical Tourism in Indonesia. Jurnal Hukum Prasada, 6 (1), h.15-21.

Utomo, A. W. (2018). Perkembangan Industri Olahraga Obyek Wisata dan Rekreasi di Kabupaten Magetan. In Prosiding Seminar Nasional Ilmu Keolahragaan UNIPMA, 1 (1), h.116-126.

Widiatedja, I. G. N. P., Arsika, I. M. B., Satyawati, N. G. A. D., \& Landra, P. T. C. (2018). Retire in Paradise: Urgensi Pengaturan Pariwisata Pensiunan (Retirement Tourism) di Indonesia. ARENA HUKUM, 11 (1), h.2-4.

\section{Website}

Bali Berkarya. (2019). Ajak Masyarakat Denpasar Hidup Sehat, Walikota Rai Mantra Buka Colour Fun Run IPC 2019. Retrieved from https://denpasarkota.go.id/baca-berita/14597/Ajak-Masyarakat-DenpasarHidup-Sehatkoma-Walikota-Rai-Mantra-Buka-Colour-Fun-Run-IPC-Bali-2019-, diakses tanggal 18 Maret 2019.

Nusa Bali. (2018). Hasil Asian Games, Momentum Anak Muda Bali. Retrieved from https://www.nusabali.com/berita/37251/hasil-asian-games-momentum-anakmuda-bali, diakses tanggal 18 Maret 2019.

Radio Republik Indonesia. (2018). Perda Keolahragaan: Babak Baru Sport Tourism di Bali. 
http://rri.co.id/post/berita/605424/berita_olahraga/perda_keolahragaan_bab ak_baru_sport_tourism_di_bali.html, diakses tanggal 18 Maret 2019.

\section{Peraturan Perundang-undangan}

Undang-Undang Nomor 3 Tahun 2005 tentang Sistem Keolahragaan Nasional, Lembaran Negara Republik Indonesia Tahun 2005 Nomor 89.

Undang-Undang Nomor 10 Tahun 2009 tentang Kepariwisataan, Lembaran Negara Republik Indonesia Tahun 2009 Nomor 11.

Peraturan Pemerintah Republik Indonesia Nomor 16 Tahun 2007 tentang Penyelenggaraan Keolahragaan, Lembaran Negara Republik Indonesia Tahun 2007 Nomor 35.

Peraturan Menteri Pariwisata Nomor 18 Tahun 2016 tentang Pendaftaran Usaha Pariwisata, Berita Negara Republik Indonesia Tahun 2016 Nomor 1551.

Peraturan Daerah Provinsi Bali Nomor 5 Tahun 2018 tentang Keolahragaan, Lembaran Daerah Bali Nomor 5 Tahun 2018. 